\title{
SPECIFIC COMPOSITION OF CHICKPEA PESTS IN THE FOREST-STEPPE OF UKRAINE
}

\author{
Mykola Dolia ${ }^{1}$ \\ mykola.dolia@gmail.com \\ Anna Kovalska ${ }^{1}$ \\ AnnTarasovna@gmail.com \\ 1Department of Integrated Protection and Plant Quarantine \\ National University of Life and Environmental Sciences of Ukraine \\ 13 Heroiv Oborony str., Kyiv, Ukraine, 03041
}

\begin{abstract}
The research aim is to improve the system of chickpea protection from pests, based on clarification of their specific composition and harmfulness under conditions of Forest-Steppe of Ukraine.

In modern field crop rotations leguminous crops cultivation favors optimization of the phytosanitary condition of agrocoenosis, and new agrarian production is provided by the effective demand for grain at not only internal, but also external markets. At that climate changes with global warming and long droughty vegetation periods of leguminous crops testify to the importance of searching for new adapted crops, resistant sorts and improved technological cultivation methods of crops, especially, chickpea, essentially influencing grain economy in whole both in Ukraine and EU.

Thus, it has been established, that ordinary chickpea (Cicer arietinum L.) is an economically, phytomedically and ecologically expedient crop from both aspects of soil fertility increase and control of the harmful organisms complex that, in its turn, it worth special attention, so sowing areas, occupied by it, are completely important. Soil-climatic conditions of Ukraine are optimal for cultivating native highly productive chickpea sorts, not inferior to foreign ones with the potential yielding capacity as $2.5-3.0 \mathrm{t} / \mathrm{ha}$.

The authors elucidate one of main control peculiarities of the insects-phytophagans under new agriculture systems. It is typical, that chickpea is a comparatively new crop in the Forest-steppe of Ukraine and doesn't favor the development, propagation and number increase of specialized pests' species. It is noted, that due to fluffing and extraction of organic acids by leaves, chickpea manifests protective properties as to pests of leaves and generative organs. But chickpea is damaged by polyphagans with harvest losses in several variants up to $50 \%$ that testifies to the elaboration topicality of modern system of crops protection from phytophagans at resource-saving cultivation technologies.
\end{abstract}

Keyrwords: chickpea, specific composition, phytophagan, monitoring, entomocomplex, pests, pests-phytophagans, polyphagans, phytosanitary condition, number counting.

DOI: $10.21303 / 2504-5695.2021 .001631$

\section{Introduction}

The obvious tendency to climate change with global warming needs revision of not only technological methods of chickpea cultivation, especially system of protective arrangements, sowing terms, standards and methods, care of crops and so on, but also needs a search for technological solutions as to crop adaptation to new structures of entomocomplexes that essentially influences the effectiveness of grain economy in the Forest-steppe of Ukraine [1].

Thus, the temperature regime increase and duration change of droughty periods in the vegetation season of 1 crops need searching for new crops, non-traditional for the cultivation region, especially such as chickpea and other grain legumes. It is most important for economies of all property forms to cultivate resistant zoned sorts of agricultural plants, and also to use a substantiated system for controlling insects'-pytophagans' complexes by organogenesis stages of their cultures, especially under unfavorable agroclimatic conditions of the last years - for increasing their yielding capacity [1-4].

It is expedient to note, that the demand for chickpea increases, and areas for it expand in the research region. In the last 10 years the area of chickpea crops has increased in more than 10 times and is today near $60-70$ thousand he $[1,3,5]$. 
At that chickpea is the most nutritive leguminous crop, containing the great amount of vitamins and other biologically-valuable substances. Grain contains 20-30 \% of protein, approximated to egg one by quality; $4-7 \%$ of fat; $2-7 \%$ of cellulose; $50-60 \%$ of carbohydrates; $2-5 \%$ of mineral substances (Ca, Mg, Fe, Zn); vitamins A, B1, B2, B3, C, B6, PP, irreplaceable amino acids. Chickpea protein is practically fat-free, so digested by $80-83 \%$ and easily assimilated, and its amino acid composition is very close to one of animal origin. The biological value of protein reaches $52-78 \%$. [2-4, 6-8].

Starting from 2010 and till today chickpea interest many agricultural producers more and more, because its yielding capacity is practically the same as one of pea. But for today chickpea is related to "niche" crops, although it has a potential for becoming the main leguminous crop, because can be cultivated on the area near $1 \mathrm{mln}$ ha $[2,3,5]$.

At the same time chickpea grain is demanded in the world, and high prices provide the high profitability, especially in 2017-2018 - 25.7-41.2 thousand hrn/ha. Expansion of sowing areas of chickpea favors the phytosanitary condition improvement, introduction of scientifically substantiated crop rotations, allowing to increase yielding capacity of other crops too in comparatively short crop rotations $[3,6,9]$.

One of main ways of chickpea yielding capacity increase is introduction of comparatively resistant sorts with modern indicators as to adaptation to soil-climatic zones and new technologies of field crops cultivation [10].

It is expedient to note, that studies as to effective protection of chickpea from insects-phytophagans in the Forest-steppe of Ukraine are practically absent. The low yielding capacity of grain in Ukraine as $0.8-1.4 \mathrm{t} / \mathrm{ha}$ in 2017-2019 is also an evidence of the fact that protection arrangements for chickpea crops in its cultivation technology are insufficiently studied. It is important to estimate the resistance of new sorts of this crop to pests, establishing optimal sowing terms and standards, influence of mineral fertilizers and expedience of using new methods of plants protection. Because of essential expansion of chickpea sowing areas, optimization of systems of crops protection from insects-phytophagans in the Forest-steppe of Ukraine is an extremely urgent task [11, 12].

The research aim is to improve the protection system of chickpea from pests.

Important research tasks are clarification of the specific composition of pests just under conditions of the Forrest-steppe of Ukraine, study of the weather factors' influence on the phytophagans' population condition, and also establishment of a damage degree of chickpea plants by main insects-phytophagans.

\section{Conditions and methods of research conduction}

2. 1. Place of research conduction, soil and agroclimatic condition in the years of research conduction

The studies were conducted in 2017-2020 at chickpea crops at SS NUBN of Ukraine "Agronomic experimental station", v. Pshenychne of the Vasylkiv district, Kyiv region, Ukraine.

As to zoning, the experimental plot is situated in the forest-steppe zone, fields are crossed by forest belts and small bushes. The soil cover is presented by the typical little-humus chernozem. This soil has the high fertility potential, provides high and stable harvests of crops.

The climate of the zone is moderately continental. Meteorological conditions in the years of research conduction were not uniform that influenced the development of phytophagans on crops, especially chickpea. In general climatic conditions are favorable for leguminous crops cultivation at observing technological requirements in agrocoenosis of the experimental plots.

\section{2. Research methods}

The experiments were conducted by conventional methods of field experiment, insects counting and harvest calculation.

Field and laboratory observations included field studies and analyses for revealing and counting pests and also determining their specific belonging.

Soil pests were counted in soil, soil bedding and on the soil surface. Determination of insects' number and condition was conducted by soil excavations. Ordinary samples of $50 \times 50 \mathrm{~cm}$ were taken at excavations in depth $50 \mathrm{~cm}[10,13,14]$. 
For counting insects that continuously move by the soil surface during the separate period of their life, land traps were used. Containers of half a liter, buried in soil to the upper side, were used as traps [15-17].

Mowing by an entomological net was conducted on plants, passing against the sun, against the wind without many waves (no more 20 before the next picking out). Using the entomological net, imago at the upper part of plants was also taken into account. A counting unit was considered 100 waves by the net, depending on number of insects, taken into account. For calculating the number of insects for the unit of area, two waves are conventionally equaled to $1 \mathrm{~m}^{2}$. Mowing was conducted at the homogenous plot of chickpea crops [10, 13, 15].

Route inspections were conducted for determining pests' dissemination and number degree in the inspection district and also the number of total fauna at temporal production experiments. Before the research beginning, sowing terms and standards, chickpea sorts and precursors were specified. First counts were conducted before sowing, next ones - taking into account the crop phenophase and season dynamics of chickpea pests' number [10, 13, 15, 16].

The degree of chickpea damage by phytophagans was established by inspecting the correspondent number of plants in different places of the studied plots, calculated healthy and damaged plants, and the percent of plants' damage was estimated [18, 19].

\section{Results}

It has been established, that one of main problems of effective chickpea cultivation is control of the pests' complex, influencing harvest quality and quantity.

\section{1. Specific composition of phytophagans}

Thus, in 2017-2019 the complex of phytophagans, colonized and damaged chickpea crops were revealed at the experimental field.

According to the monitoring results of the chickpea complex, 17 species of harmful insects of 9 families that to one or another extent damaged this crop at the main organogenesis stages were revealed (Table 1).

\section{Table 1}

Specific composition of phytophagans on chickpea crops (Kyiv region, Vasilkyv district, v. Pshenychne 2017-2019)

\begin{tabular}{|c|c|c|}
\hline Order & Family & Specie \\
\hline \multirow{3}{*}{ Lepidoptera } & Pyraustidae & Acacia pickleworm (Etiella zinckenella) \\
\hline & Noctuidae & Cotton moth (Helicoverpa armigera Hüb.), winter moth (Scotiasegetum) \\
\hline & Scarabaeidae & Western may-bug (Melolontha melolontha L.) \\
\hline \multirow{3}{*}{ Coleoptera } & Tenebrionidae & $\begin{array}{l}\text { Broad-chested midlyak (Blaps lethifera), steppe midlyak (Blaps halophila), } \\
\text { sand midlyak (Opatrum sabulosum) }\end{array}$ \\
\hline & Elateridae & $\begin{array}{l}\text { Dark grasshopper (Agriotes obscurus), sowing grasshopper (Agriotes } \\
\text { sputator L.), wide grasshopper (Selatosomus latus F.) }\end{array}$ \\
\hline & Curculionidae & $\begin{array}{c}\text { Grey southern weevil (Tanymecus dilaticollis), striped nodular weevil } \\
\text { (Sitona lineatus Germ.), bristly nodular weevil ( Sitona crinitus Hrb.), } \\
\text { leguminous nodular weevil ( Sitona tibialis Hrbst.) }\end{array}$ \\
\hline \multirow{2}{*}{ Diptera } & Agromyzidae & Mining fly (Liriomyza cicerina Rod.), \\
\hline & Anthomyiidae & Sprout fly (Delia platura) \\
\hline Homoptera & Aphididae & Pea plant-louse (Acyrthosiphon pisum) \\
\hline
\end{tabular}

The main composition of entomofauna included 4 orders. The order bugs (Coleoptera) was characterized by the most specific diversity.

\section{2. Structure of the harmful chickpean entomocomplex}

The share of Coleoptera in the entomocomplex structure was $63.2 \%$ of the total number of revealed species. The order Lepidoptera counted 3 species from Pyraustidae and Noctuidae fami- 
lies and took $17.6 \% .2$ species of phytophagans from the Diptera order, related to the Agromyzidae and Anthomyiidae families, were revealed that are $11.7 \%$ from the total entomocomplex share. The number of Homoptera in the entomocomplex structure was 5.8 \% (1 type from the Aphididae, family, and other $-1.7 \%$ ) (Fig. 1)

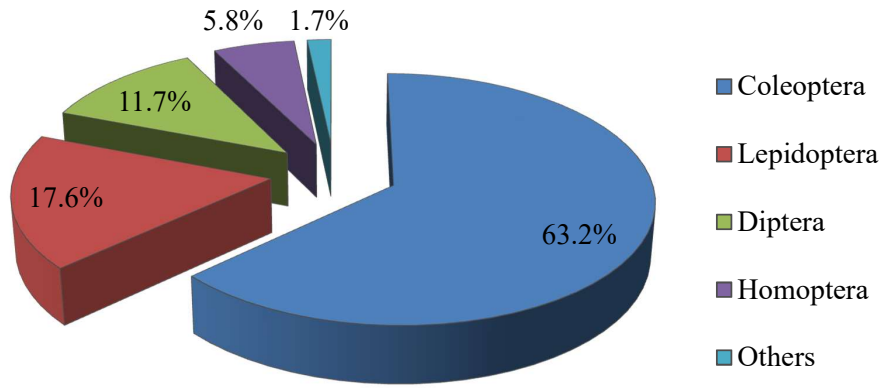

Fig. 1. Structure of the chickpea harmful entomocomplex (SS NUBN "Agronomic experimental station" for 2017-2019)

\section{3. Damage degree of chickpea plants by the main insects-phytophagans}

It has been established, that the comparatively high damage degree of chickpea plants is caused by acacia pickleworm, leguminous moth and mining fly. In the years of observation the damage degree of chickpea plants by acacia pickleworm was $26.7-33.3 \%$, increasing in 2018 . Leguminous moth damaged $6.7-11.8 \%$ of plants. The damage degree of chickpea plants by the mining fly somewhere reached $72.2 \%$ that was observed in 2018. It is expedient to take into account at modern technologies of chickpea crops protection from the complex of insects-phytophagans.

Damage degree fluctuations of separate species of pests, connected with favorable weather conditions and comparatively intensive organogenesis indices of chickpea in winter, were observed (Table 2).

Table 2

Damage degree of chickpea by the main pests (SS NUBN “Agronomic experimental station" for 2017-2019)

\begin{tabular}{|c|c|c|c|c|}
\hline Phytophagan & Yearк & $\begin{array}{c}\text { Average number of } \\
\text { plants in a sample un } / \mathrm{m}^{2}\end{array}$ & $\begin{array}{c}\text { Average number of dam- } \\
\text { aged plants, un } / \mathrm{m}^{2}\end{array}$ & $\begin{array}{c}\text { Damage degree of } \\
\text { plants, } \%\end{array}$ \\
\hline \multirow{3}{*}{ Acacia pickleworm } & 2017 & 15 & 4 & 26.7 \\
\hline & 2018 & 18 & 6 & 33.3 \\
\hline & 2019 & 17 & 5 & 29.4 \\
\hline \multirow{3}{*}{ Leguminous moth } & 2017 & 15 & 1 & 6.7 \\
\hline & 2018 & 18 & 2 & 11.1 \\
\hline & 2019 & 17 & 2 & 11.8 \\
\hline \multirow{3}{*}{ Mining fly } & 2017 & 15 & 10 & 66.7 \\
\hline & 2018 & 18 & 13 & 72.2 \\
\hline & 2019 & 17 & 11 & 64.7 \\
\hline
\end{tabular}

\section{Discussion of research results}

In the research years the number dynamics of the revealed insects-phytophagans was influenced, first of all, by abiotic, biotic and anthropic factors. Thus, the beginning of chickpea plants colonization by pests in the spring vegetation period was noted in the first April decade. Changes of the chickpea phytophagans structure during the vegetation period were established by peculiarities and growth intensity of the plants. It has been noted, that the plants are damaged by wireworms, midlyaks, may-bug larvae, winter moth caterpillars, sprout fly larvae and weevil imago from sprouts to the beginning of bushing, and in the intensive growth phase - peas formation, the plants are damaged 
by mining fly larvae, acacia pickleworm caterpillars, plant-louses; in the grain ripening phase - complete ripeness, mass colonization of the crop by cotton moth caterpillars is observed.

According to the results of the conducted studies, it has been for the first time established, that the main and comparatively dangerous pests, causing the veritable damage to chickpea in the observation region, are: acacia pickleworm, leguminous and winter moth, mining fly, wireworm and western may-bug, whereas the damage of crop plants by other species of pests is not essential. It is expedient to take into account at modern control systems of the complex of harmful insects' species.

It has been established, that changeable, often unfavorable hydrothermal conditions (insufficient soil moistening, increased air temperatures) restrained the development and harmfulness of sowing and wide grasshoppers. In the vegetation period of 2019 the harmfulness of black bugs and grasshopper larvae turned out low as $0.5-5 \%$ of plants. Autumn soil inspections revealed wireworms at $50 \%$ of the studied areas that are by $5 \%$ less than last year (55\% of the studied areas). The veritable density decrease of wintering larvae, comparing with the last year, from 0.9 to 0.8 un for $\mathrm{m}^{2}$ was noted. Despite the decrease of the average number of wireworms in comparatively well moistened places, the maximal number of pests varied from 2 to 5 un for $\mathrm{m}^{2}$. In general, colonization of the studied plots was $52 \%$, by $6 \%$ less than last year, at average number $0.6-0.8$, max $0.9-1.1$ un for $\mathrm{m}^{2}$ in the Kyiv region.

The development and harmfulness of may-bug larvae were also restrained by unfavorable weather conditions in the spring period and by droughts in the second half of vegetation. The inspection in autumn of 2019 revealed pests' larvae at $47.4 \%$ of the studied areas with average number $1.0 \mathrm{un} / \mathrm{m}^{2}$ that is at the previous year level. In general, plots of the research region, mostly colonized by may-bugs, varied from $37 \%$ to $53.3 \%$ with average maximal number $1.7 \mathrm{un} / \mathrm{m}^{2}$.

\section{Conclusions}

17 species of harmful pests of 9 families, damaged both vegetating plants (up to $37 \%$ ), and grain (up to $16 \%$ ) have been revealed in the Forest-steppe of Ukraine in chickpea crops.

The main and comparatively dangerous pests, causing the veritable damage to chickpea, are: acacia pickleworm (7-11 un/ $\mathrm{m}^{2}$ ), leguminous and winter moth (up to $4 \mathrm{un} / \mathrm{m}^{2}$ ), mining fly (12$16 \mathrm{un} / \mathrm{m}^{2}$ ), wireworm (up to $6 \mathrm{un} / \mathrm{m}^{2}$ ) and western may-bug (up to $9 \mathrm{un} / \mathrm{m}^{2}$ ), whereas the damage of crop plants by other species of pests is not essential. It is expedient to take into account at modern systems and technologies of this crop protection at economies of all property forms.

Based on the conducted monitoring, the season and many years number dynamics of the complex of chickpea pests, controlled by the integrated protective system, allowing to get grain harvest 2.1-2.5 t/ha, has been established.

\section{Conflict of interests}

The paper has not conflicting interests

\section{References}

[1] Adamenko, T. I. (2016). Zmina ahroklimatychnykh umov ta yikh vplyv na zernovi hospodarstva. Ahronom, 3, $12-15$.

[2] Husarova, A. (2019). Bobovi u sivozmini: znachennia, cherhuvannia ta perevahy. SuperAgronom. Available at: https://superagronom.com/articles/237-bobovi-u-sivozmini-znachennya-cherguvannya-ta-perevagi

[3] Kvitko, H. P., Mykhalchuk, D. P., Karasevych, V. V. (2013). Prespektyvy vyroshchuvannia nutu posivnoho v umovakh Lisostepu Ukrainy. Kormy i kormovyrobnytstvo, 75, 113-120.

[4] Sichkar V., Bushulian, O. (2001). Tekhnolohiya vyroshchuvannia nutu v Ukraini. Propozytsiya, 10, 42-43.

[5] Sichkar, V. I. (2002). Stan i perspektyvy selektsiyi zernobobovykh kultur v Selektsiyno-henetychnomu instytuti UAAN. Zb. nauk. prats Selektsiyno-henetychnoho Instytutu - Natsionalnoho tsentru nasinnieznavstva ta sortovyvchennia, 3 (43), 92-103.

[6] Sichkar, V. I., Bushulian, O. V. (2007). Nut. Botanichna kharakterystyka, biolohichni osoblyvosti, ahrotekhnika ta novi sorty. Odessa: SHI-NATs NAIS, 24.

[7] Sichkar, V. I. (2004). Rol zernobobovykh kultur u vyrishenni bilkovoi problemy v Ukraini. Kormy i kormovyrobnytstvo, 53, 110-115. 
[8] Kholodova, O. Yu. (2011). Kharakterystyka pozhyvnykh vlastyvostei nutu ta suchasnyi stan yoho vykorystannia u kharchoviy promyslovosti. Tovaroznavstvo ta innovatsiyi, 3, 165-170.

[9] Skytskyi, V. Yu., Herasymova, Yu. I. (2010). Analiz kolektsiyi nutu dlia vykorystannia na pidvyshchennia tekhnolohichnosti pry vyroshchuvanni. Henetychni resursy roslyn, 8, 40-45.

[10] Sichkar, V. I., Ptashnyk, O. P., Bushulian, O. V. (2014). Urozhainist nutu v zalezhnosti vid sortu ta tekhnolohiyi vyroshchuvannia. Ahrarnyk. Available at: https://agrarnik.com/index.php?option=com_k2\&view=item\&id=2748:urozhajnist-nutu-v-zalezhnosti-vid-sortu-ta-tekhnologiji-viroshchuvannya\&Itemid=434

[11] Lisoval, A. P., Makarenko, V. M., Kravcheko, S. M. (2002). Systema zastosuvannia dobryv. Kyiv: Vyshcha shk., 317.

[12] Tolkachov, M. Z. (2003). Optymizatsiya symbiozu bobovykh roslyn i bulbochkovykh bakteriy v suchasnomu kormovyrobnytstvi. Kormy i vyrobnytstvo, 51, 133-136.

[13] Omeliuta, V. P., Hryhorovych, I. V., Chaban, V. S. (1986). Oblik shkidnykiv i khvorob s/h kultur. Kyiv: Urozhai, 296.

[14] Rekomendatsiyi po obsledovaniyu sel's'kohozyaystvennyh ugodiy na zaselennost' vreditelyami i zarazhennost' boleznyami (1981). Kyiv: Urozhay.

[15] Dolia, M. M, Pokoziy, Y. T., Mamchur, R. M. et. al. (2004). Fitosanitarnyi monitorynh. Kyiv, 294.

[16] Megalov, V. A. (1968). Vyyavlenie vrediteley polevyh kul'tur. Moscow: Kolos, 176.

[17] Paliy, V. F. (1970). Metodika izucheniya fauny i fenologi nasekomyh. Tsentral'no-chernozemnoeknizhnoe izdatel'stvo. Voronezh, 192.

[18] Kulieshov, A. V., Bilyk, M. Shch. (2008). Fitosanitarnyi monitorynh i prohnoz. Kharkiv: Espada, 512.

[19] Trybel, S. O. (Ed.) (1986). Oblik shkidnykiv i khvorob silskohospodarskykh kultur. Kyiv: Urozhai, 71-78. 